\title{
INTEGRACJA FINANSOWA A SYNCHRONIZACJA CYKLI KONIUNKTURALNYCH POLSKI I UNII EUROPEJSKIEJ
}

\begin{abstract}
Streszczenie
Cykle koniunkturalne gospodarek, ze względu na postępujący proces globalizacji gospodarki światowej, są w coraz większym stopniu od siebie zależne. W procesie globalizacji kraje wschodzące zwiększyły swoje znaczenie gospodarcze na świecie, jednocześnie upodobniając się do krajów wysoko rozwiniętych gospodarczo. Nowa struktura gospodarki światowej powoduje istotne implikacje dla cykli koniunkturalnych większości krajów świata. Jednym z czynników, który istotnie przyczynia się do większej współzależności cykli koniunkturalnych na świecie, są dynamicznie rosnące międzynarodowe przepływy inwestycji zagranicznych (tzw. integracja finansowa).

Celem niniejszego opracowania jest analiza oddziaływania międzynarodowych przepływów kapitałowych na synchronizację cykli koniunkturalnych Polski oraz Unii Europejskiej w okresie 2005-2013. W pracy wykorzystano metodę badawczą oparta na studiach literaturowych z zakresu makroekonomii i finansów międzynarodowych oraz metody ekonometryczne (modele wektorowej autoregresji - Vector Autoregression Model. Wyniki przeprowadzonych badań empirycznych wskazuja, że wzrost obrotów kapitałowych niekoniecznie prowadzi do zwiększenia synchronizacji cykli koniunkturalnych analizowanych gospodarek. Wpływ wzrostu przepływów kapitałowych krajów na synchronizację ich cykli koniunkturalnych zależy nie tylko od intensywności obrotów kapitałowych, ale przede wszystkim od struktury rodzajowej tych obrotów.
\end{abstract}

Słowa kluczowe: inwestycje zagraniczne, cykl koniunkturalny, konwergencja

\section{FINANCIAL INTEGRATION AND BUSINESS CYCLE SYNCHRONISATION IN POLAND AND EUROPEAN UNION}

\section{Summary}

Due to the process of globalisation in the world economy, business cycles are becoming increasingly interdependent. Under globalisation, emerging countries have increased their economic weight in the world, at the same time conforming to the economically developed countries. The new structure of the global economy causes significant implications for business cycles in most countries of the world. Among the factors that contribute significantly to greater interdependence of business cycles are rapidly growing international flows of foreign investment (i.e. financial integration).

The purpose of this paper is to analyse the impact of international capital flows on the synchroni-sation of business cycles in Poland and the European Union in the period of 2005-2013. The author uses a research method based on the study of relevant literature on macroeconomics and international finance, as well as econometric methods (Vector Autoregression Model -VAR). The results of empirical studies indicate that the increase in capital movements does not necessarily lead to an increase in business cycle synchronisa-

\footnotetext{
${ }^{1}$ Dr hab. Piotr Misztal, prof. nadzw. - Wydział Zarządzania i Administracji, Uniwersytet Jana Kochanowskiegow Kielcach; e-mail: misztal@tkdami.net.
} 
tion in the analysed economies. The impact of the growth of capital flows on business cycle synchronisation depends not only on the intensity of capital movements, but mainly on the structure of capital flows.

Key words: foreign investment, business cycle, convergence

DOI: $10.15290 /$ ose.2015.02.74.01

\section{Wstęp}

Problematyka dotycząca synchronizacji cykli koniunkturalnych oraz jej głównych determinant jest niezwykle istotna z kilku powodów. Po pierwsze, bardziej zsynchronizowane cykle koniunkturalne oznaczają silniejszą i szybszą transmisję szoków ekonomicznych między poszczególne kraje, co może stanowić istotną przesłankę międzynarodowej koordynacji polityk ekonomicznych krajów. Po drugie, synchronizacja cykli koniunkturalnych ma ważne implikacje dla konstruowania i funkcjonowania wspólnych obszarów walutowych. Wreszcie po trzecie, jeśli cykle koniunkturalne są w największym stopniu zdeterminowane czynnikami zewnętrznymi, wówczas krajowe polityki prowadzone w celu stabilizacji koniunktury gospodarczej będa prawdopodobnie mało efektywne.

Analiza stopnia synchronizacji wahań koniunkturalnych gospodarek, czyli korelacji cyklicznego komponentu produktu krajowego brutto (PKB), stała się współcześnie kluczową kwestią w dyskusji dotyczącej procesów integracji gospodarczej krajów. Szczególne zainteresowania ekonomistów są związane z kwestią analizy występowania procesów konwergencji (zbieżności) oraz dywergencji (rozbieżności) cykli koniunkturalnych w Unii Europejskiej, w tym w zwłaszcza w strefie euro. Stąd pojawia się pytanie, czy cykle koniunkturalne krajów członkowskich Unii Europejskiej stają się w coraz większym, czy coraz mniejszym stopniu zsynchronizowane w czasie? Jeżeli rzeczywiście występuje proces dywergencji gospodarczej, to prowadzenie wspólnej polityki gospodarczej, w tym np. polityki pieniężnej, może nie być jednakowo efektywne z punktu widzenia pojedynczych krajów lub regionów Unii Europejskiej.

\section{Synchronizacja cykli koniunkturalnych i jej główne determinanty w świetle teorii}

Stopień synchronizacji cykli koniunkturalnych dwóch krajów albo regionów definiuje się jako zbieżność stóp wzrostu gospodarczego w czasie, przejawiającą się korelacją cyklicznego komponentu realnego PKB. Stopień synchronizacji cykli koniunkturalnych jest zdeterminowany wieloma czynnikami o charakterze endogenicznym. Do najważniejszych czynników endogenicznych zalicza się przy tym: intensywność wymiany handlowej, stopień podobieństwa struktur gospodarczych oraz stopień integracji finansowej.

Zgodnie z ujęciem teoretycznym może występować dwukierunkowy wpływ integracji handlowej na korelację cykli koniunkturalnych. Z jednej strony, jeżeli dominuja- 
cym czynnikiem zmian koniunkturalnych w kraju jest kanał popytowy, to wzrost stopnia integracji handlowej krajów może przyczynić się do zwiększenia stopnia korelacji cykli koniunkturalnych krajów. Z drugiej strony, jeśli dominującą siłą oddziałującą na cykl koniunkturalny są czynniki związane $z$ dana gałęzia przemysłu, to wzrost obrotów handlowych między krajami może doprowadzić do zmniejszenia stopnia korelacji cykli koniunkturalnych lub do jego zwiększenia w zależności od znaczenia wymiany wewnątrz- i międzygałęziowej.

Jeżeli w obrotach handlowych krajów dominuje handel międzygałęziowy, wówczas wzrost specjalizacji w różnych gałęziach przemysłu sprawia, że oddziaływanie integracji handlowej na synchronizację cykli koniunkturalnych jest negatywne. Jeśli z kolei w obrotach handlowych krajów dominuje wymiana wewnątrzgałęziowa, wówczas struktura towarowa handlu analizowanych krajów jest zbliżona, co może powodować pozytywny wpływ integracji handlowej na synchronizację cykli koniunkturalnych.

O ile analizy teoretyczne potwierdzaja generalnie pozytywny wpływ integracji handlowej na synchronizację cykli koniunkturalnych krajów, to wpływ integracji finansowej na korelację cykli koniunkturalnych nie jest jednoznaczny. W literaturze przedmiotu wskazuje się kilka kanałów, którymi integracja finansowa oddziałuje na synchronizację cykli koniunkturalnych krajów. Jednym z nich jest kanał popytowy, zgodnie z którym jeśli konsumenci utrzymują swoje aktywa na zagranicznym rynku kapitałowym, to spadek wartości akcji na tym rynku prowadzi do spadku aktywów konsumentów i zgłaszanego przez nich popytu. W tej sytuacji dodatkowo może wystapić efekt zarażenia (contagion effect), który przyczynia się do rozprzestrzenienia tych skutków na międzynarodowe rynki finansowe [Allen, Gale, 2000, s. 1-33].

Z kolei w teorii realnego cyklu koniunkturalnego stwierdza się, że postępująca integracja finansowa krajów prowadzi do większej możliwości podziału ryzyka, mniejszej zmienności i większej synchronizacji konsumpcji w tych krajach. Jednocześnie w teorii realnego cyklu koniunkturalnego zakłada się, że w miarę wzrostu stopnia integracji finansowej krajów zmniejsza się stopień synchronizacji inwestycji między krajami ze względu na swobodny przepływ kapitału do krajów o wyższej krańcowej produktywności kapitału. Ostatecznie, zgodnie z teorią realnego cyklu koniunkturalnego, wzrost stopnia integracji finansowej gospodarek wywołuje spadek stopnia synchronizacji cykli koniunkturalnych krajów [Islamaj, 2013, s. 1-38].

$\mathrm{Na}$ stopień synchronizacji cykli koniunkturalnych wpływa również stopień podobieństwa struktur gospodarczych (przemysłowych) oraz stopień specjalizacji, skoro szoki ekonomiczne dotyczące danej dziedziny przemysłu powodują większy wzrost synchronizacji cykli koniunkturalnych w krajach o zbliżonych strukturach produkcji, niż w gospodarkach o asymetrycznych strukturach produkcji [mbs, 2004, s. 723-734]. 
RYSUNEK 1.

Synchronizacja cykli koniunkturalnych i jej główne determinanty

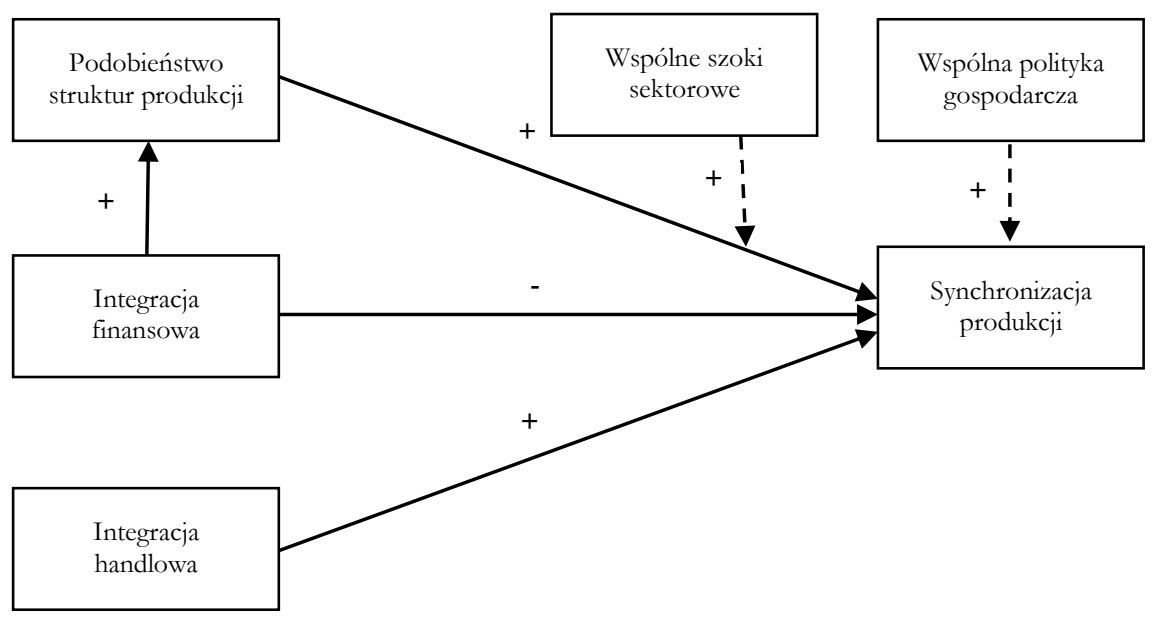

Źródło: [García-Herrero, Ruiz, 2008, s. 12].

Zatem, zgodnie z ujęciem teoretycznym, integracja finansowa krajów wpływa na synchronizację ich cykli koniunkturalnych w sposób bezpośredni i pośredni. Mianowicie, integracja finansowa negatywnie oddziałuje w sposób bezpośredni na synchronizację cykli koniunkturalnych, zaś pozytywnie wpływa w sposób pośredni, tzn. poprzez oddziaływanie na podobieństwo struktur produkcji.

\section{Integracja finansowa a synchronizacja cykli koniunkturalnych w świetle wyników wybranych analiz empirycznych}

Badania empiryczne związane z problematyką synchronizacji cykli koniunkturalnych opierają się na dwóch alternatywnych podejściach. Pierwsza grupa badań empirycznych koncentruje się na analizie stopnia synchronizacji cykli koniunkturalnych w czasie w wybranych krajach lub grupach krajów, natomiast druga grupa badań dotyczy analizy najważniejszych czynników determinujących stopień synchronizacji cykli koniunkturalnych w różnych gospodarkach.

Zgodnie z wynikami badań przeprowadzonych przez Krugmana [Krugman, 1991], proces integracji gospodarczej prowadzi do bardziej asymetrycznych wahań koniunkturalnych, czego skutkiem jest mniejsza synchronizacja cykli koniunkturalnych. Wyniki badań przeprowadzonych przez Camacho, Perez-Quiros i Saiz [Camacho, PerezQuiros, Saiz, 2006, s. 1-31] również sugerują, że integracja gospodarcza przyczynia się do zwiększenia regionalnej koncentracji działalności gospodarczej, czego rezultatem jest powstawanie sektorowych lub regionalnych szoków ekonomicznych, zwiększają- 
cych prawdopodobieństwo pojawiania się szoków asymetrycznych oraz rozbieżnych cykli koniunkturalnych.

Jednym z czynników determinujących zbieżność cykli koniunkturalnych gospodarek jest intensywność i struktura wzajemnych obrotów kapitałowych krajów. Jednakże w świetle wyników przeprowadzonych analiz empirycznych wpływ wzajemnych obrotów kapitałowych dwóch krajów na synchronizację ich cykli koniunkturalnych nie jest jednoznaczny. Devereux i Yetman [Devereux, Yetman, 2010, s. 71-105] oraz Devereux i Sutherland [Devereux, Sutherland, 2011, s. 427-442] sugerowali, że wpływ przepływów kapitałowych na synchronizację cykli koniunkturalnych zależy od typu integracji finansowej (rysunek 2.).

RYSUNEK 2.

\section{Kanały wpływu inwestycji zagranicznych na synchronizację cykli} koniunkturalnych

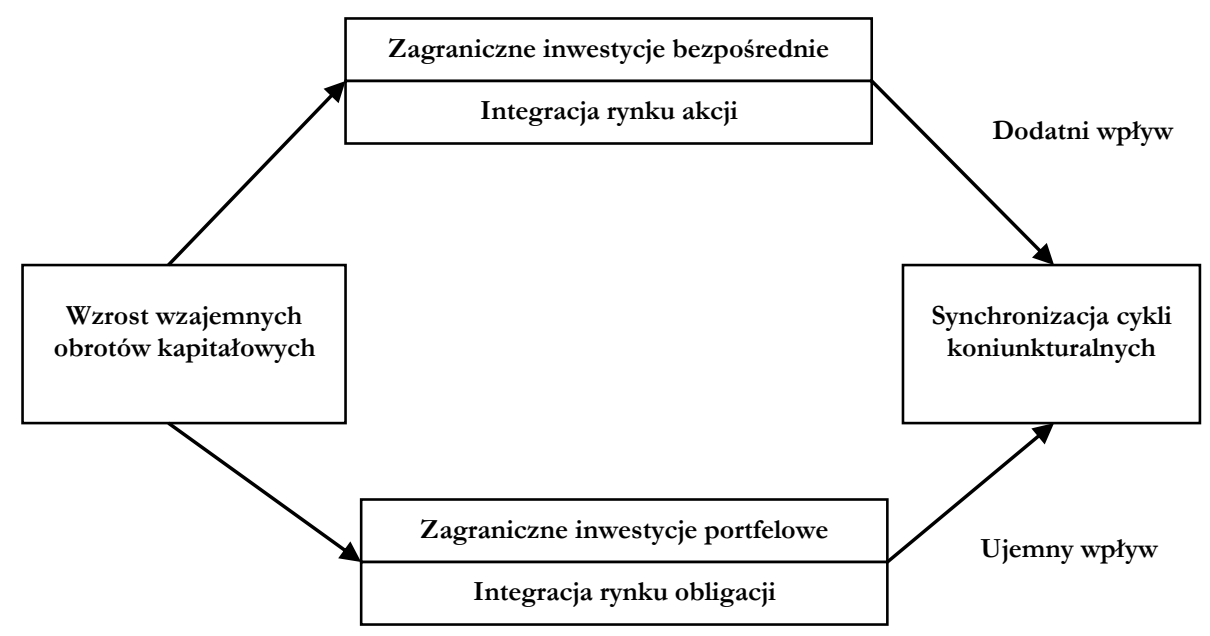

Źródło: opracowanie własne.

O ile wzrost przepływów zagranicznych inwestycji portfelowych (większa integracja rynku obligacji) wywołuje niższą korelację cykli koniunkturalnych, to wzrost przepływów zagranicznych inwestycji bezpośrednich (większa integracja rynku akcji) powoduje większą transmisję szoków technologicznych między krajami, przyczyniając się do większej synchronizacji cykli koniunkturalnych.

Wyniki badań przeprowadzonych przez Dées i Zorell w okresie 1993-2007 [Dées, Zorell, 2011, s. 1-21] na grupie 30 krajów członkowskich OECD również wskazuja, że integracja finansowa w sposób pośredni wpływa na synchronizację cykli koniunkturalnych przez wzrost stopnia podobieństwa struktur produkcji krajów. Poprzez ten pośredni kanał integracja finansowa prowadzi do wzrostu stopnia synchronizacji cykli koniunkturalnych gospodarek. 
Scott [Scott, 2009, s. 1-57] także sugeruje, że ostateczny wpływ integracji finansowej na synchronizację cykli koniunkturalnych zależy od typu integracji finansowej. Jednakże, jego zdaniem, wzrost integracji rynków kapitałowych przyczynia się do spadku stopnia synchronizacji cykli koniunkturalnych gospodarek, zaś wzrost integracji rynków kredytowych prowadzi do zwiększenia stopnia korelacji cykli koniunkturalnych krajów.

Kalemli-Ozcan, Papaioannou, Peydró [Kalemli-Ozcan, Papaioannou, Peydró, 2009, s. 1-12] stwierdzają, że wpływ integracji finansowej krajów na synchronizację cykli koniunkturalnych gospodarek nie jest związany z czynnikami zależnymi od badanych krajów, lecz jest uzależniony od szoków globalnych. Wyniki badań przeprowadzonych przez tych ekonomistów na grupie 20 krajów wysoko rozwiniętych gospodarczo w okresie 30 lat wskazuja negatywne oddziaływanie integracji finansowej na synchronizację cykli koniunkturalnych analizowanych krajów.

Z kolei wyniki analizy przeprowadzonej przez Busl i Kappler [Busl, Kappler, 2013, s. 1-31] wśród krajów członkowskich OECD i Unii Europejskiej w okresie 1982-2009 ukazuja pozytywne oddziaływanie zagranicznych inwestycji bezpośrednich na synchronizację cykli koniunkturalnych w krajach członkowskich OECD i Unii Europejskiej oraz całkowity brak wpływu tych inwestycji na zbieżność cykli koniunkturalnych w strefie euro.

\section{Integracja finansowa a synchronizacja cykli koniunkturalnych w ujęciu modelowym}

W literaturze ekonomicznej dokonuje się najczęściej pomiaru oddziaływania integracji finansowej na synchronizację cykli koniunkturalnych w krajach lub grupach krajów przy pomocy różnorodnych modeli ekonometrycznych, bazujących na modelu zaproponowanym przez Frankel i Rose [Frankel, Rose, 1998, s. 1009-1025]. W niniejszym opracowaniu model obrazujący wpływ integracji finansowej na synchronizację cykli koniunkturalnych gospodarek przedstawia się w postaci poniższego równania:

$$
\operatorname{Corr}_{i j t}=c+\alpha F I_{i j t}+\varepsilon_{i j t},
$$

gdzie:

Corrijt - synchronizacja cykli koniunkturalnych krajów $i$ oraz $j$ w okresie $t$, $F_{i j t}$ - intensywność przepływów kapitałowych między krajami $i$ oraz $j$ w okresie $t$, $\alpha$-współczynnik oddziaływania intensywności przepływów kapitałowych krajów $i$ oraz $j$ na synchronizację ich cykli koniunkturalnych;

$c$ - wyraz wolny równania;

$\varepsilon_{i j t}-$ składnik losowy.

Do pomiaru stopnia synchronizacji cykli koniunkturalnych krajów wykorzystuje się indeks synchronizacji cykli koniunkturalnych (Business Cycles Synchronization - BCS) skonstruowany przez Frankel, Rose [Frankel, Rose, 1998, s. 1009-1025] oraz Akin [Akin, 2006, s. 1-57] i przedstawia się w postaci następującego wyrażenia: 


$$
B C S_{i j}=\frac{\operatorname{cov}\left(y_{i}^{c}, y_{j}^{c}\right)}{\sqrt{\operatorname{var}\left(y_{i}^{c}\right) \operatorname{var}\left(y_{j}^{c}\right)}},
$$

gdzie:

$B C S_{i j}$ - indeks synchronizacji cykli koniunkturalnych krajów $i$ oraz $j$;

$y_{i}^{c}$ - realna dynamika produktu krajowego brutto w kraju $i$, po usunięciu trendu za pomoca filtru Hodricka-Presscotta;

$y_{j}^{c}$ - realna dynamika produktu krajowego brutto w kraju $j$, po usunięciu trendu za pomoca filtru Hodricka-Presscotta.

Dodatnia wartość współczynnika synchronizacji cykli koniunkturalnych świadczy o występowaniu synchronizacji cykli koniunkturalnych między krajami $i$ oraz $j$. Natomiast ujemna wartość współczynnika synchronizacji cykli koniunkturalnych oznacza brak synchronizacji cykli koniunkturalnych krajów w $i$ oraz $j$.

Z kolei do pomiaru intensywności wzajemnych przepływów kapitałowych krajów wykorzystuje się indeks intensywności przepływu inwestycji zagranicznych, obliczany według poniższego wyrażenia:

$$
F I_{i j}=\frac{F I O U T_{i j t}+F I I N_{i j t}}{G D P_{i t}+G D P_{j t}} \cdot 100 \%
$$

gdzie:

$F I O U T_{i j t}$ - wartość odpływu inwestycji zagranicznych z kraju $i$ do kraju $j$ w okresie $t$, $F I I N_{i j t}$ - wartość napływu inwestycji zagranicznych z kraju $j$ do kraju $i$ w okresie $t$, $G D P_{i t}-$ wartość PKB w kraju $i$ w okresie $t$, $G D P_{i j}-$ wartość PKB w kraju $j$ w okresie $t$.

Wskaźnik intensywności przepływu inwestycji zagranicznych jest wykorzystywany do określenia, czy przepływy inwestycji zagranicznych między dwoma krajami są większe lub mniejsze niż można byłoby oczekiwać na podstawie ich potencjału gospodarczego. Indeks ten może przyjmować wartości większe, równe lub mniejsze od jedności. Wartość wskaźnika wyższa (niższa) od jedności świadczy o tym, że dwustronne przepływy inwestycji zagranicznych są większe (mniejsze) niż oczekiwano, uwzględniajac potencjały badanych gospodarek.

Biorąc pod uwagę możliwość odmiennego wpływu zagranicznych inwestycji bezpośrednich i zagranicznych inwestycji portfelowych na synchronizację cykli koniunkturalnych badanych gospodarek, celowe jest wyodrębnienie w wykorzystywanym modelu odmiennych typów inwestycji zagranicznych.

Intensywność przepływów zagranicznych inwestycji bezpośrednich mierzy się przy pomocy wskaźnika intensywności zagranicznych inwestycji bezpośrednich (Foreign Direct Investment Intensity Index - FDIII) przedstawionego w postaci poniższego wyrażenia:

$$
F D I I I_{i j}=\frac{F D I O U T_{i j t}+F D I I N_{i j t}}{G D P_{i t}+G D P_{j t}} \cdot 100 \%,
$$


gdzie:

$F_{\text {FIOUT }}$ - wartość odpływu zagranicznych inwestycji bezpośrednich z kraju $i$ do kraju $j$ w okresie $t$;

FDIIN $N_{i j t}$ - wartość napływu zagranicznych inwestycji bezpośrednich z kraju $j$ do kraju $i \mathrm{w}$ okresie $t$,

$G D P_{i t}$ - wartość PKB w kraju $i$ w okresie $t$;

$G D P_{i j}$ - wartość PKB w kraju $j$ w okresie $t$.

Wskaźnik intensywności przepływu zagranicznych inwestycji bezpośrednich jest wykorzystywany do określenia, czy przepływy zagranicznych inwestycji bezpośrednich między dwoma krajami są większe lub mniejsze niż można byłoby oczekiwać na podstawie ich potencjału gospodarczego.

Natomiast o kształtowaniu się intensywności wzajemnych przepływów zagranicznych inwestycji portfelowych świadczy wartość wskaźnika intensywności zagranicznych inwestycji portfelowych (Foreign Porffolio Investment Intensity Index - FDIII), przedstawionego w postaci poniższego wyrażenia:

$$
F P I I I_{i j}=\frac{F P I O U T_{i j t}+F P I I N_{i j t}}{G D P_{i t}+G D P_{j t}} \cdot 100 \%,
$$

gdzie:

FPIOUT $_{i j t}$ - wartość odpływu zagranicznych inwestycji portfelowych z kraju $i$ do kraju $j$ w okresie $t$,

FPIIN $N_{j i t}$ - wartość napływu zagranicznych inwestycji portfelowych z kraju $j$ do kraju $i \mathrm{w}$ okresie $t$,

$G D P_{i t}$ - wartość PKB w kraju $i$ w okresie $t$,

$G D P_{i j}$ - wartość PKB w kraju $j$ w okresie $t$.

Wskaźnik intensywności przepływu zagranicznych inwestycji portfelowych wykorzystuje się do określenia, czy dwustronne przepływy zagranicznych inwestycji portfelowych są większe lub mniejsze niż można byłoby oczekiwać na podstawie potencjału gospodarczego analizowanych krajów.

W celu analizy oddziaływania stopnia intensywności przepływów zagranicznych inwestycji bezpośrednich i zagranicznych inwestycji portfelowych na synchronizację cykli koniunkturalnych w Polsce i Unii Europejskiej w okresie 2005-2013 wykorzystano model, który ostatecznie przedstawia się w poniższy sposób:

$$
B C S_{P L_{-} U E}=c+\alpha F D I I_{P L_{-} U E}+\beta F P I I_{P L_{-} U E}+\varepsilon_{P L_{-} U E},
$$

gdzie:

$B C S_{P L_{-} U E}$ - wskaźnik synchronizacji cykli koniunkturalnych Polski i Unii Europejskiej (26 krajów członkowskich);

FDIIPL_UE - wskaźnik intensywności przepływów zagranicznych inwestycji bezpośrednich między Polską i Unią Europejską (26 krajów członkowskich); FPII PL_UE $_{-}$- wskaźnik intensywności przepływów zagranicznych inwestycji portfelowych między Polską i Unią Europejską (26 krajów członkowskich); 
$\varepsilon_{P L \_U E}-$ składnik losowy.

Wszystkie wymienione powyżej zmienne modelu miały częstotliwość kwartalną i obejmowały okres od pierwszego kwartału 2005 roku do trzeciego kwartału 2013 roku. Zgodnie z poniższym rysunkiem, w przypadku większości lat z okresu 2005-2013 miały miejsce zarówno dodatnie, jak i ujemne wartości współczynników synchronizacji cykli koniunkturalnych Polski i Unii Europejskiej, co świadczyło o istotnej zmianie w czasie stopnia synchronizacji cykli koniunkturalnych między Polską i Unią Europejską (rysunek 3.).

RYSUNEK 3.

Współczynniki synchronizacji cykli koniunkturalnych (BCS) Polski z Unią Europejską w okresie Q1.2005-Q3.2013

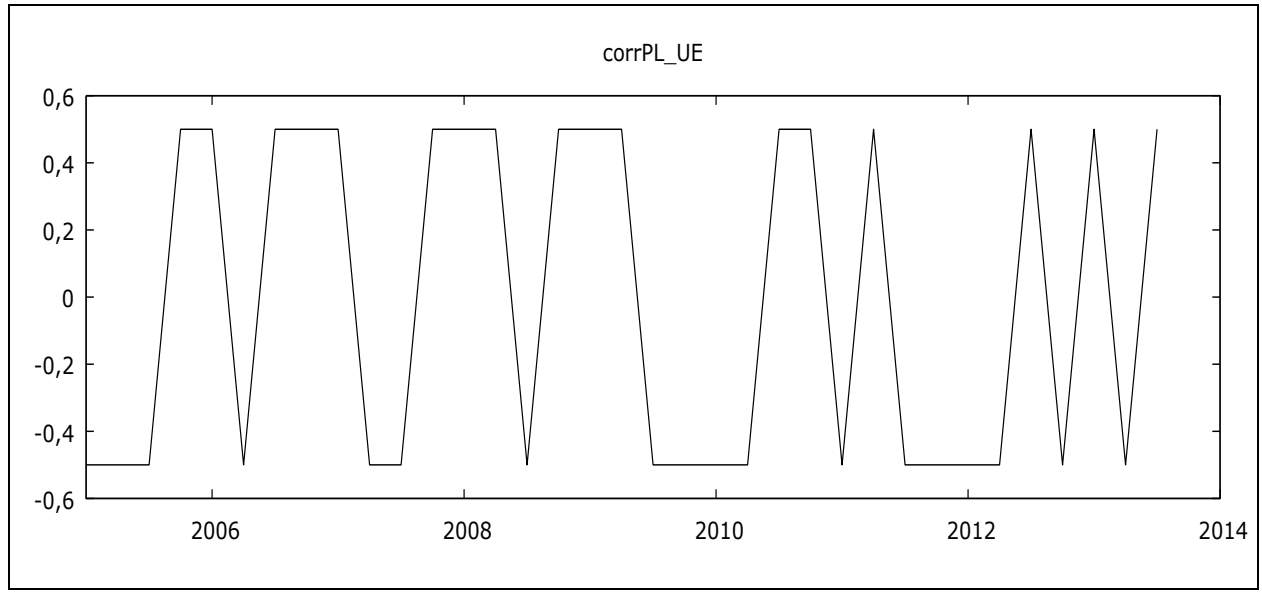

Źródło: opracowanie własne na podstawie danych: [Eurostat Database, 2014].

Z kolei na podstawie rysunku 4. można zauważyć, iż intensywność przepływów zagranicznych inwestycji bezpośrednich między Polską i Unią Europejską wykazywała generalnie tendencję wzrostową w okresie 2005-2013, przy czym największy wzrost wskaźnika intensywności przepływów zagranicznych inwestycji bezpośrednich zaobserwowano na przełomie 2006 i 2007 roku. Odmiennie kształtowały się zmiany intensywności przepływów zagranicznych inwestycji portfelowych między Polską i Unią Europejską. Otóż wskaźnik intensywności przepływów zagranicznych inwestycji portfelowych odznaczał się w tym przypadku znaczną zmiennością, a największe wartości przyjmował w okresie od końca 2006 roku do końca 2009 roku. Jednocześnie intensywność przepływów zagranicznych inwestycji portfelowych była kilkukrotnie niższa w porównaniu z intensywnością przepływów zagranicznych inwestycji bezpośrednich (rysunek 4.). 
RYSUNEK 4.

Wskaźniki intensywności przepływu zagranicznych inwestycji bezpośrednich i portfelowych między Polską i Unią Europejską w okresie Q1.2005-

Q3.2013

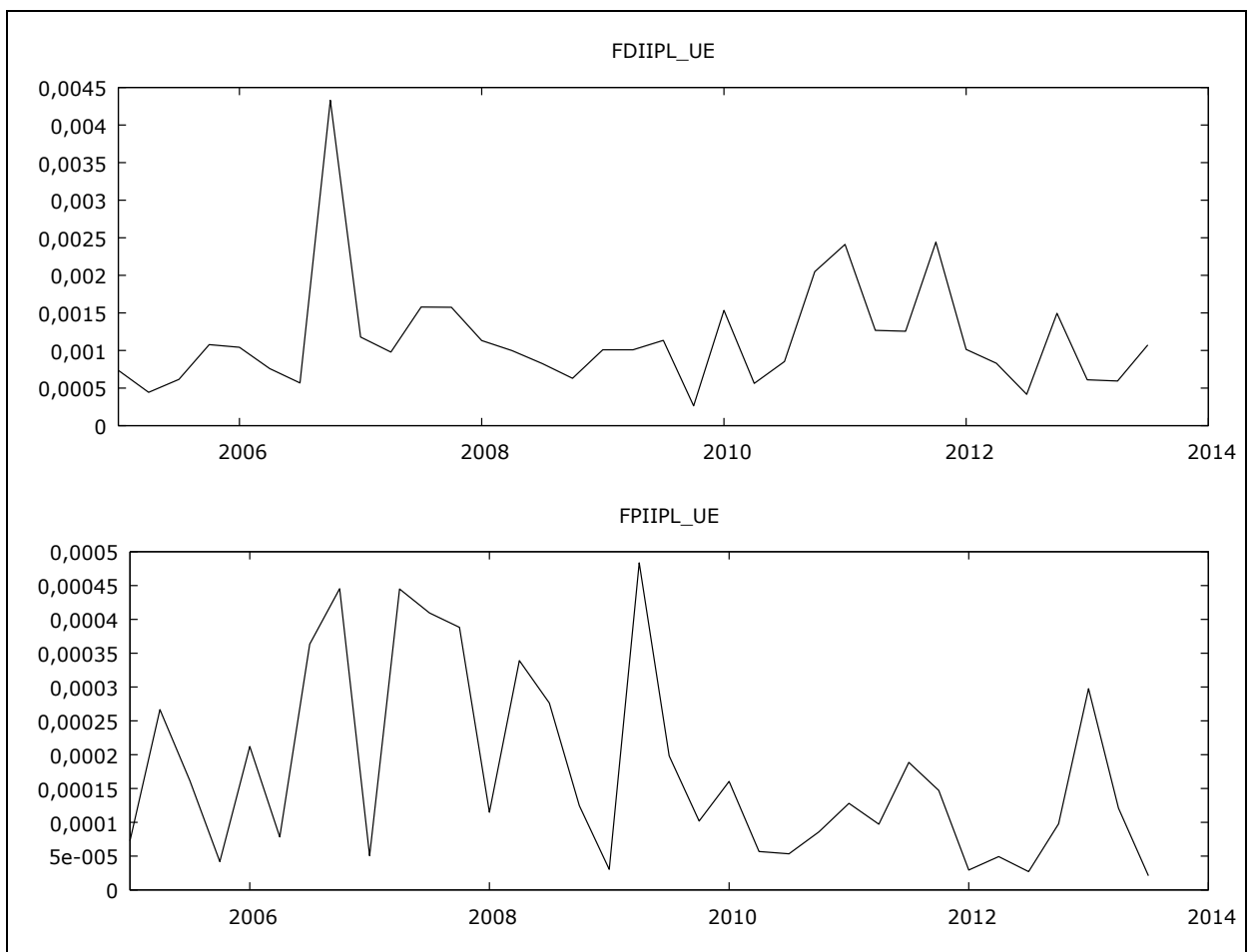

Źródło: opracowanie własne na podstawie danych: [Eurostat Database, 2014].

Przed dokonaniem estymacji modeli wyjaśniających wpływ integracji finansowej na synchronizację cykli koniunkturalnych Polski i Unii Europejskiej było niezbędne określenie stacjonarności wykorzystywanych szeregów czasowych, gdyż nieuwzględnienie ewentualnego braku stacjonarności szeregów czasowych mogłoby spowodować występowanie regresji pozornej między zmiennymi. W tym celu wykorzystano rozszerzony test Dickeya-Fullera - ADF (Augmented Dickey-Fuller). Wyniki rozszerzonego testu ADF wskazywały na pojawienie się szeregów czasowych o rzędach integracji: 0 i 1 . Odpowiednie wyniki testów ADF przedstawiono w tabeli 1. 
TABELA 1.

Wyniki analizy stacjonarności zmiennych modelu

\begin{tabular}{|c|c|}
\hline Szereg czasowy & $\begin{array}{l}\text { Rząd in- } \\
\text { tegracji }\end{array}$ \\
\hline $\begin{array}{l}B C S_{P L U E E}-\text { wskaźnik synchronizacji cykli koniunkturalnych Polski i Unii } \\
\text { Europejskiej }\end{array}$ & $I(0)$ \\
\hline $\begin{array}{l}F D I I_{P L_{L} U E}-\text { wskaźnik intensywności przepływów zagranicznych inwesty- } \\
\text { cji bezpośrednich między Polską i Unią Europejską }\end{array}$ & $I(1)$ \\
\hline $\begin{array}{l}\text { FPII } I_{P L U E} \text { - wskaźnik intensywności przepływów zagraniczi } \\
\text { portfelowych między Polską i Unią Europejską }\end{array}$ & $1(T)$ \\
\hline
\end{tabular}

Źródło: opracowanie własne.

Brak stacjonarności dwóch szeregów czasowych, uwzględnionych w modelu, wymusił modyfikacje postaci funkcyjnej modelu. Modyfikacja polegała na zastąpieniu wielkości analizowanych zmiennych przez ich pierwsze różnice. Jednocześnie, ze względu na brak występowania pierwiastka jednostkowego we wszystkich szeregach czasowych oraz brak kointegracji między zmiennymi modelu, nie było możliwości rozszerzenia i przekształcenia modelu w wektorowy model korekty błędem.

W analizie przyjęto jeden okres opóźnień między zmiennymi objaśniającymi a zmienną objaśniana (jeden kwartał). Dokonany wybór rzędu opóźnień był zgodny z wynikami kryteriów informacyjnych modeli Schwartza-Bayesiana oraz Hannana-Quinna. Według tych kryteriów, największą pojemność informacyjną miał model z jednym opóźnieniem (tabela 2.).

\section{Wyniki kryteriów informacyjnych}

TABELA 2.

\begin{tabular}{|l|}
\hline Opóźnienia loglik p(LR) AIC BIC HQC \\
$188,76970-5,697835-5,269627 *-5,566928^{*}$ \\
$297,316200,04728-5,665443-4,809026-5,403628$ \\
$3105,553500,05761-5,610964-4,326338-5,218241$ \\
$4112,762860,10819-5,483061-3,770227-4,959431$ \\
$5125,652620,00222-5,760902-3,619859-5,106364$ \\
$6141,640580,00020-6,260041 *-3,690790-5,474596$ \\
\hline
\end{tabular}

Gwiazdka $(*)$ wskazuje najlepszą (to jest minimalna) wartość dla odpowiednich kryteriów informacyjnych, AIC = kryterium Akaike'a, BIC = kryterium Schwartza-Bayesiana i HQC = kryterium Hannana-Quinna.

Źródło: opracowanie własne.

Następnie dokonano estymacji równania (6) przy pomocy modelu wektorowej autoregresji zaproponowanego przez Simsa [Sims, 1980, s. 1-48]. W metodzie VAR analizuje się dane zjawisko za pomocą układu równań, co zgodnie z postulatem Simsa [Sims, 
1980, s. 1-48] eliminuje jednocześnie problem egzogeniczności zmiennych objaśniających. Wyniki oszacowań parametrów strukturalnych równania (6) przedstawiono w tabeli 3.

TABELA 3.

System VAR (model wektorowej autoregresji), rząd opóźnienia 1. Estymacja KMNK dla obserwacji 2005:1-2013:3

\begin{tabular}{|lccccc|}
\hline \multicolumn{7}{|c|}{ Równanie: BCSEU } \\
\hline d_BCSEU_1 & $-0,456138$ & 0,108902 & $-4,1885$ & 0,00023 & $* * *$ \\
d_FDIIEU_1 & 1,57682 & 0,866306 & 1,8202 & 0,07873 & $*$ \\
d_FPIIEU_1 & $-11,9657$ & 5,21755 & $-2,2934$ & 0,02901 & $* *$ \\
\hline \multicolumn{7}{c}{ W } & & & & \\
\hline Średn.aryt.zm.zależnej & 0,030303 & Odch.stand.zm.zależnej & 0,728219 \\
Suma kwadratów reszt & 11,20208 & Błąd standardowy reszt & 0,611067 \\
Wsp. determ. R-kwadrat & 0,341054 & Skorygowany R-kwadrat & 0,297124 \\
F(3, 30) & 5,175752 & Wartość p dla testu F & 0,005303 \\
Autokorel.reszt - rho1 & $-0,060040$ & Stat. Durbina-Watsona & 2,101948 \\
\hline
\end{tabular}

Źródło: opracowanie własne.

Na podstawie wyników oszacowań równania BCSEU można zauważyć, iż synchronizacja cykli koniunkturalnych Polski i Unii Europejskiej była w badanym okresie w istotnym stopniu zdeterminowana kształtowaniem się intensywności przepływów zagranicznych inwestycji bezpośrednich i portfelowych między Polską i Unią Europejską. Obliczony współczynnik oddziaływania intensywności przepływów zagranicznych inwestycji bezpośrednich na zbieżność cykli koniunkturalnych wyniósł 1,57, co tym samym potwierdzało pozytywny wpływ zagranicznych inwestycji bezpośrednich na korelację cykli koniunkturalnych Polski i Unii Europejskiej. Natomiast współczynnik oddziaływania intensywności przepływów zagranicznych inwestycji portfelowych na synchronizację cykli koniunkturalnych wyniósł $-11,9$, co tym razem świadczyło o negatywnym i znacznie większym wpływie zagranicznych inwestycji portfelowych na zbieżność cykli koniunkturalnych badanych gospodarek.

Zatem wyniki przeprowadzonych badań były zgodne z ujęciem teoretycznym, wskazującym na pozytywny wpływ zagranicznych inwestycji bezpośrednich i negatywne oddziaływanie zagranicznych inwestycji portfelowych na synchronizację cykli koniunkturalnych analizowanych krajów. Co więcej, negatywny wpływ zagranicznych inwestycji portfelowych był kilkukrotnie wyższy od pozytywnego wpływu zagranicznych inwestycji bezpośrednich na zbieżność cykli koniunkturalnych. Uzyskane rezultaty badań są więc zbieżne z wynikami badań empirycznych, przeprowadzonych przez Devereux i Yetman [Devereux, Yetman, 2010, s. 71-105] oraz Devereux i Sutherland [Devereux, Sutherland, 2011, s. 427-442].

Następnym etapem badania był pomiar siły oddziaływania zagranicznych inwestycji bezpośrednich i portfelowych na synchronizację cykli koniunkturalnych Polski i Unii Europejskiej w okresie 2005-2013. Pomiaru tego dokonano przy pomocy tzw. funkcji 
odpowiedzi impulsowych (impulse response function), czyli funkcji reakcji wskaźnika synchronizacji cykli koniunkturalnych na impuls w postaci zmiany wskaźników intensywności przepływów zagranicznych inwestycji bezpośrednich i portfelowych między Polską i pozostałymi krajami Unii Europejskiej (rysunek 5.).

RYSUNEK 5. Funkcje odpowiedzi impulsowych wskaźnika synchronizacji cykli koniunkturalnych Polski i Unii Europejskiej

d_BCSEU -> d_BCSEU

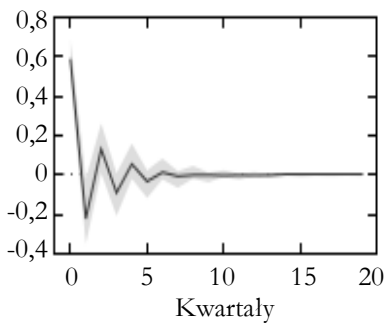

d_FDIIEU -> d_BCSEU

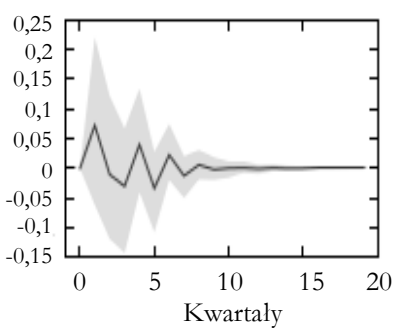

d_FPIIEU -> d_BCSEU

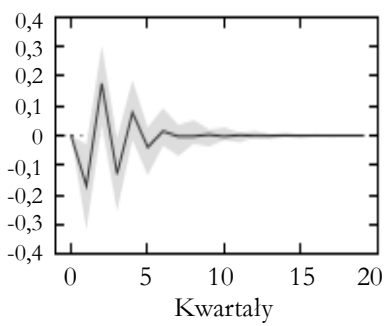

Źródło: opracowanie własne.

Na podstawie powyższych rysunków można zauważyć, iż szokowy wzrost wskaźnika synchronizacji cykli koniunkturalnych Polski i Unii Europejskiej prowadził do natychmiastowego wzrostu wartości tego wskaźnika w ciagu pierwszego kwartału od momentu pojawienia się szoku, a następnie do spadku i stopniowej stabilizacji po upływie kolejnych dwóch kwartałów. Natomiast wzrost wskaźnika intensywności przepływów zagranicznych inwestycji bezpośrednich między Polską a Unią Europejską prowadził do stopniowego wzrostu wskaźnika synchronizacji cykli koniunkturalnych badanych gospodarek w ciagu dwóch kolejnych kwartałów od momentu wystąienia szoku, a dalej do stopniowego spadku i stabilizacji w trakcie kolejnych pięciu kwartałów. Odmiennie reagował wskaźnik synchronizacji cykli koniunkturalnych Polski i Unii Europejskiej na wzrost wskaźnika intensywności przepływów zagranicznych inwestycji portfelowych między analizowanymi gospodarkami. Mianowicie, szokowy wzrost wskaźnika intensywności przepływów zagranicznych inwestycji portfelowych przyczynił się do stopniowego spadku wskaźnika synchronizacji cykli koniunkturalnych Polski i Unii Europejskiej, a później do stopniowego wzrostu i stabilizacji po upływie kolejnych pięciu kwartałów.

Ostatnim etapem analizy była dekompozycja wariancji składnika resztowego współczynnika synchronizacji cykli koniunkturalnych Polski i Unii Europejskiej w okresie 2005-2013, w celu oszacowania wpływu zmian współczynników intensywności przepływu zagranicznych inwestycji bezpośrednich i portfelowych na kształtowanie się zmienności współczynnika synchronizacji cykli koniunkturalnych (rysunek 6.). 
RYSUNEK 6.

Dekompozycja wariancji współczynnika synchronizacji cykli koniunkturalnych Polski i Unii Europejskiej

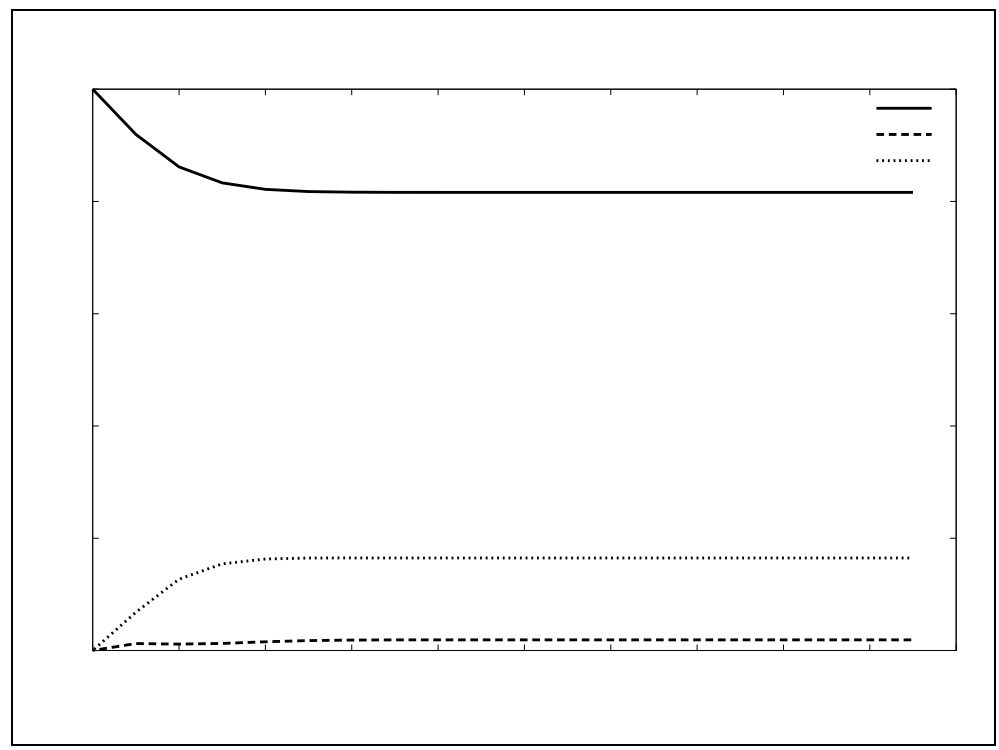

Źródło: opracowanie własne.

Uwzględniając dekompozycję wariancji współczynnika synchronizacji cykli koniunkturalnych Polski i Unii Europejskiej, można zauważyć, iż w największym stopniu zmienność synchronizacji cykli koniunkturalnych wyjaśniono przez czynnik inercyjny. Natomiast zmienność współczynnika synchronizacji cykli koniunkturalnych wyjaśniono w około 4\% przez zmiany współczynnika intensywności przepływu zagranicznych inwestycji bezpośrednich oraz w około $18 \%$ przez zmiany współczynnika intensywności przepływu zagranicznych inwestycji portfelowych.

\section{Podsumowanie}

Przeprowadzone badania empiryczne dotyczące wpływu integracji finansowej (międzynarodowych przepływów kapitałowych) na synchronizację cykli koniunkturalnych Polski i Unii Europejskiej wykazały, że wzrost wzajemnych przepływów inwestycji zagranicznych niekoniecznie prowadzi do zwiększenia synchronizacji cykli koniunkturalnych analizowanych gospodarek. Mianowicie, wpływ przepływu inwestycji zagranicznych dwóch krajów na synchronizację ich cykli koniunkturalnych zależy nie tylko od intensywności tych przepływów, ale przede wszystkim od struktury rodzajowej inwestycji zagranicznych.

Wzrost inwestycji zagranicznych powoduje większą zbieżność cykli koniunkturalnych gospodarek tylko wtedy, gdy są to zagraniczne inwestycje bezpośrednie prowadzące 
do wzrostu stopnia podobieństwa struktur produkcji krajów i przyczyniające się do powstawania symetrycznych szoków ekonomicznych. Z kolei wzrost wzajemnych przepływów zagranicznych inwestycji portfelowych gospodarek wywołuje spadek stopnia synchronizacji cykli koniunkturalnych i może powodować powstawanie częstych szoków asymetrycznych.

Uzyskane wyniki badań mają istotne implikacje z punktu widzenia przyszłego członkostwa Polski w unii walutowej krajów członkowskich Unii Europejskiej. Innymi słowy, skoro wzrost przepływu zagranicznych inwestycji bezpośrednich Polski i pozostałych krajów Unii Europejskiej prowadzi do większej korelacji cykli koniunkturalnych gospodarek, to koszty związane z brakiem autonomicznej polityki monetarnej w obliczu asymetrycznych szoków ekonomicznych będa mniejsze w sytuacji członkostwa Polski w unii walutowej. Tym samym korzyści netto, wynikające z członkostwa Polski w unii walutowej, okażą się większe w warunkach rosnącego stopnia podobieństwa struktur gospodarczych Polski i Unii Europejskiej. Zatem rezultaty badań mogą stanowić jeden $z$ istotnych argumentów wspierających dążenia Polski do pełnego członkostwa w unii monetarnej krajów członkowskich Unii Europejskiej.

\section{Literatura}

Akin C. 2006 Multiple Determinants of Business Cycle Synchronization, George Washington University, Department of Economics, Washington.

Allen F., Gale D. 2000 Financial contagion, „Journal of Political Economy”, no. 108.

Busl C., Kappler M. 2013 Does Foreign Direct Investment Synchronise Business Cycles? Results from a Panel Approach, „WWWforEurope Working Paper”, no. 23.

Camacho M., Perez-Quiros G., Saiz L. 2006 Are European business cycles close enough to be just one?, ,Journal of Economics Dynamics and Control”, no. 30.

Devereux M. B., Sutherland A. 2011 Evaluating International Financial Integration under Leverage Constraints, „European Economic Review”, no. 55(3).

Devereux M. B., Yetman J. 2010 Leverage Constraints and the International Transmission of Shocks, ,Journal of Money, Credit and Banking", no. 42(6).

Dées S., Zorell N. 2011 Business Cycle Synchronisation Disentangling Trade and Financial Linkages, „European Central Bank Working Paper Series”, no. 1322.

Eurostat Database 2014, European Commission, Luxembourg.

Frankel J., Rose A. 1998 The Endogenity of the Optimum Currency Area Criteria, „The Economic Journal”, no. 108.

García-Herrero A., Ruiz J. M. 2008 Do trade and financial linkages foster business cycle synchronization in a small economy?, „Banco de Espania Working Papers”, no. 0810.

Imbs J. 2004 Trade, Finance, Specialization, and Synchronization, „Review of Economics and Statistics", no. 86.

Islamaj E. 2013 Industrial specialization, financial integration, and international consumption risk sharing, „Vassar College Working Paper”, dokument elektroniczny, tryb dostępu: [http://http://irving.vassar.edu/faculty/ei/Outline7.pdf]. 
Kalemli-Ozcan S., Papaioannou E., Peydró J. L. 2009 Financial Integration and Business Cycle Synchronization, „CEPR Discussion Papers”, no. 7292.

Krugman P.R. 1991 Geography and Trade. Cambridge, MIT Press, Massachusetts.

Scott D. 2009 Financial Integration and International Business Cycle Co-movement: The Role of Financial Sector Risk, Dissertation Vanderbilt University.

Sims Ch. A. 1980 Macroeconomics and Reality, „Econometrica”, vol. 1. 